\title{
Influence of temperature, concentration and shear rate on the rheological behavior of malay apple (Syzygium malaccense) juice
}

\author{
Influência da temperatura, concentração e taxa de deformação no \\ comportamento reológico do suco de jambo-vermelho (Syzygium malaccense)
}

\author{
Pedro Henrique Santos ${ }^{1 *}$, Luiza Helena Meller da Silva ${ }^{2}$, Antônio Manoel da Cruz Rodrigues², \\ José Antonio Ribeiro de Souza ${ }^{1}$ \\ ${ }^{1}$ Universidade Federal de Santa Catarina (UFSC), Departamento de Engenharia Química e Engenharia de Alimentos (EQA), Campus Trindade, \\ Florianópolis/SC - Brasil \\ 2 Universidade Federal do Pará (UFPA), Programa de Pós-graduação em Tecnologia de Alimentos, Belém/PA - Brasil
}

\section{${ }^{*}$ Corresponding Author}

Pedro Henrique Santos, Universidade Federal de Santa Catarina (UFSC), Departamento de Engenharia Química e Engenharia de Alimentos (EQA), Campus Trindade, Rua Roberto Sampaio Gonzaga, s/n, CEP: 88040-900, Florianópolis/SC - Brasil, e-mail: phs.ufsc@yahoo.com.br

Cite as: Influence of temperature, concentration and shear rate on the rheological behavior of malay apple (Syzygium malaccense) juice. Braz. J. Food Technol., v. 19, e2015009, 2016.

Received: Mar. 19, 2015; Accepted: May 11, 2016

\section{Summary}

The aim of this study was to evaluate the rheological behavior of malay apple, a traditional Amazonian fruit with high bioactive properties, at different temperatures and soluble solids concentrations. The experiments were carried out in a Brookfield R/S Plus rheometer with concentric cylinders geometry. Power Law, Herschel-Bulkley, Mizrahi-Berk, and Sisko rheological models were fitted to the experimental data. The malay apple juice (pulp and skin) showed a pseudoplastic behavior for all temperatures and concentrations with flow behavior indexes lower than 1. The temperature effect on the samples' apparent viscosity was analyzed by the Arrhenius equation. The activation energy increased with a decrease in the soluble solids concentration, showing that the lower the concentration, the greater the temperature influence on the apparent viscosity. The soluble solids effect was described by the exponential equation. The exponential factor increased with the temperature increasing, showing that the higher the temperature, the greater the effect of the soluble solids concentration on samples' apparent viscosity. Finally, a triparametric mathematical model combining temperature, concentration, and shear rate was proposed aiming to evaluate its effects on the samples' apparent viscosity and has accurately adjusted to the data with high correlation index $\mathrm{R}^{2}$.

Keywords: Rheology; Malay apple; Temperature; Concentration; Shear rate.

\section{Resumo}

O objetivo deste estudo foi avaliar o comportamento reológico do suco de jambo-vermelho, uma tradicional fruta da região amazônica com elevadas propriedades bioativas, a diferentes temperaturas e concentrações de sólidos solúveis. Os experimentos foram realizados em um reômetro Brookfield R/S Plus, operando em geometria de cilindros concêntricos. Os modelos reológicos da Lei da Potência, Herschel-Bulkley, Mizrahi-Berk e Sisko foram utilizados para modelagem dos dados experimentais. O suco de jambo-vermelho (polpa e casca) apresentou comportamento pseudoplástico para todas as temperaturas e concentrações, com índice de comportamento de fluxo menor que 1. O efeito da temperatura na viscosidade aparente das amostras foi analisado pela equação de Arrhenius. A energia de ativação aumentou com a diminuição na concentração dos sólidos solúveis, atestando que, quanto menor a concentração, maior a influência da temperatura na viscosidade aparente. O efeito da concentração de sólidos solúveis foi descrito pela equação exponencial. O fator exponencial aumentou sob aumento da temperatura, atestando que, quanto maior for a temperatura, maior será o efeito dos sólidos solúveis na viscosidade aparente das amostras. Por fim, um modelo matemático triparamétrico, relacionando temperatura, concentração de sólidos solúveis e taxa de deformação foi proposto, visando avaliar a influência destes parâmetros na viscosidade aparente das amostras e, de forma satisfatória, ajustou-se aos dados experimentais, com elevado índice de correlação R².

Palavras-chave: Reologia; Jambo-vermelho; Temperatura; Concentração; Taxa de deformação. 


\section{Introduction}

Native from Malaysia, malay apple (Syzygium malaccense), also known as mountain apple, is a traditional fruit from the Amazon region. Oblong-shaped and with pleasant sensory qualities, malay apple is a very good source of bioactive compounds. According to Augusta et al. (2010), malay apple is rich in vitamin C and anthocyanins and, similarly to the major Myrtaceae fruits, these compounds are mainly located in the fruit's skin.

In Brazil, where the fruit is known as "jambo-vermelho", the area cultivated with malay apple, due to the ease of cultivation and appropriate climatic conditions, has experienced a considerable expansion, mainly on the north and northeast regions where the fruit is mostly consumed in natura. Usually, in the fruit industrial processing into other forms of products such as juices, concentrated juices, nectars, purées, syrups, jellies, and ice creams, the raw material is subjected to different industrialization processes and knowing its physicochemical properties is very important. In this respect, rheological behavior plays an essential role, not only as a quality measure, but also for designing and optimizing the processing plants (KESHANI et al., 2012; VANDRESEN et al., 2009; PELEGRINE et al., 2002).

Due to the importance of rheological properties in fluid mechanics, rheological models are used as key tools to describe the flow behavior of fluid foods. The simplest type of rheological behavior is the Newtonian one. However, most fluid foods do not display this simple behavior, requiring more complex models for their characterization. Some models have been applied to quantify how magnitudes of model parameters are affected by state variables, such as temperature, and the effect of composition (solids concentration) (TONON et al., 2009).

According to Telis-Romero et al. (1999), rheological models that express the dependence of rheological properties on temperature and on water content are a very appealing alternative to experimentation and a key tool for equipment selection. The Arrhenius equation is often used to describe the effect of temperature on apparent viscosity or on the consistency coefficient of food fluids. The effect of concentration on apparent viscosity or on the consistency coefficient of food fluids can be described either by the potential or exponential equations (STEFFE, 1996).

Therefore, the aim of this study was to determine the rheological behavior of malay apple juice prepared from fresh fruits with skin. This goal included producing and studying the juice's flow behavior as well as modeling the experimental data using rheological models, in particular the effect of temperature and soluble solids concentration on the flow. Finally, a triparametric model was proposed relating temperature, concentration, and shear rate as functions for apparent viscosity predictions. Since in industrial operations a fluid food at different concentrations is submitted to a range of shear rates and temperatures, it is essential to know how the fluid viscosity will change at these variables to appropriately design the equipment for these operations.

\section{Material and methods}

\subsection{Acquisition and processing}

Malay apple juice was extracted from a single lot of fresh malay apple fruits collected from university botanic garden (UFPA, Belém, Brazil). The fruits were chosen based on skin color (reddish color), appearance (few mechanical damages), and ripeness degree. They were washed in running water to remove surface dirt, dipped in 100 ppm sodium hypochlorite for $15 \mathrm{~min}$, and washed again. Fruits were then individually cut for seed removal and processed for about $30 \mathrm{~s}$ in an $\mathrm{HC} 31$ domestic blender (Black \& Decker, Uberaba, Brazil). The juice was packed in polyethylene bags $(100 \mathrm{~g})$ to reduce contact with air and then quickly frozen and stored at $-18^{\circ} \mathrm{C}$.

\subsection{Physicochemical properties}

Moisture, $\mathrm{pH}$, soluble solids, total solids, and titratable acidity in the juice and in all formulations were determined according to the standard IAL methods (IAL, 2008). Moisture and total solids were determined by gravimetric method, at $105^{\circ} \mathrm{C}$, up to constant weight. Soluble solids and $\mathrm{pH}$ were determined in a 0767BO Abbe refractometer (Quimis, São Paulo, Brazil) and a DHMP1 pH meter (Digimed, São Paulo, Brazil) at $25^{\circ} \mathrm{C}$, respectively. Titratable acidity was determined by potentiometric titration with $0.1 \mathrm{~N} \mathrm{NaOH}$ up to $\mathrm{pH} 8.1$ and the results were expressed as percentage of citric acid.

\subsection{Rheological measurements}

The malay apple juice concentrates were diluted in distilled water, in proportions of 20,30, and $40 \mathrm{~g}$ of water/100 $\mathrm{g}$ of sample, followed by the determination of the soluble solids concentration ( ${ }^{\circ}$ Brix).

The rheological measurements were carried out using a Brookfield R/S Plus controlled-shear-rate rheometer (Brookfield Engineering Labs, Middleboro-MA, USA) with concentric cylinder geometry (CC25). The tests were performed at $10^{\circ} \mathrm{C}, 30^{\circ} \mathrm{C}, 50^{\circ} \mathrm{C}$, and $70^{\circ} \mathrm{C}$. The temperature was controlled by a LAUDA 3200 thermostatic bath (Lauda, Lauda-Königshofen - Germany), properly attached to the rheometer.

The shear stress and apparent viscosity data were obtained in a controlled rate method ranging from 0 to $300 \mathrm{~s}^{-1}$ on the upward curve, and 300 to $0 \mathrm{~s}^{-1}$ on the downward curve. According to Steffe (1996), food processing involving mixing, stirring and pipe flow requires a shear 
rate range from 1 to $1000 \mathrm{~s}^{-1}$. The total run time for each ascending and descending curve was 5 min; shear stress and apparent viscosity values were obtained every $7.5 \mathrm{~s}$, resulting in 40 points. All the analyses were carried out in duplicate. The upward and downward curves virtually did not vary, indicating the absence of the thixotropic effect.

After each experimental run, a new sample of the raw material was used, avoiding changes in rheological properties.

\subsection{Analyses and modeling}

The Power Law (Equation 1), Herschel-Bulkley (Equation 2), Mizrahi-Berk (Equation 3), and Sisko (Equation 4) models were applied to the rheological data in order to fit the best representative model. The rheological data were obtained by the Rheo3000 software (Brookfield Engineering Labs, Middleboro-MA, USA), and the parameters were determined with Microsoft Excel 2010 (Microsoft Corporation, Redmond-WA, USA) and Origin 8.0 (OriginLab, Northampton-MA, USA).

$$
\begin{aligned}
& \tau=K \dot{y}^{n} \\
& \tau=\tau_{0}+K_{H B} \dot{\gamma}^{n_{H B}} \\
& \tau^{0.5}=K_{0_{M B}}+K_{M B} \dot{\gamma}^{n_{M B}} \\
& \tau=\mu_{\infty} \dot{\gamma}+K_{S} \dot{\gamma}^{n_{S}}
\end{aligned}
$$

The Power Law is a classical model, highly representative for fruit juices and easy to fit, employing only two adjusting parameters. The Herschel-Bulkley model was the first one to present the yield stress parameter $\left(\tau_{0}\right)$, a relevant content on the study of the fluid flow. The Mizrahi-Berk model was developed as a modified Casson model (RAO, 1999). The Sisko model is an equation with three parameters which presents the viscosity parameter at infinite shear rate $\left(\mu_{\infty}\right)(\mathrm{RAO}, 1999)$. According to Nindo et al. (2007), this model has been widely used for rheological representation of fluids at high shear rates.

\subsubsection{Effect of temperature, concentration, and shear rate on rheological behavior}

The effect of temperature on apparent viscosity was described by the Arrhenius equation (Equation 5) (RAO, 1999) at a constant shear rate of $100 \mathrm{~s}^{-1}$, where $A_{0}$ is a pre-exponential factor, $E_{A}$ is the activation energy, $R$ is the universal gas constant $(0.008314 \mathrm{~kJ} / \mathrm{mol} . \mathrm{K})$ and $T$ is the absolute temperature.

$$
\mu=A_{0} \exp \left(\frac{E_{A}}{R T}\right)
$$

The effect of soluble solids concentration on apparent viscosity was described by an exponential equation (Equation 6) (KHALIL et al., 1989) at a constant shear rate of $100 \mathrm{~s}^{-1}$, where $A_{1}$ is the pre-exponential factor, $B_{1}$ is the concentration factor, and $C$ is the soluble solids concentration.

$$
\mu=A_{1} \exp \left(B_{1} C\right)
$$

Both (Equation 5) and (Equation 6) were linearized to obtain the constants $A_{0}, E_{A}, A_{1}$ and $B_{1}$.

For engineering applications, it is very useful to obtain a single equation describing the combined effect of temperature and concentration on the fluid's apparent viscosity (STEFFE, 1996; IBARZ et al., 1992; IBARZ et al., 1996; KAYA; BELIBAGLI, 2002; QUEK et al., 2013).

The combined effect of temperature and concentration on the apparent viscosity of malay apple samples is described by combining the Arrhenius and exponential equations (Equation 7) (TELIS-ROMERO et al., 1999), where $A_{2}, B_{2}$ and $E_{A}$ are constants to be determined.

$$
\mu=A_{2} \exp \left(B_{2} C+\frac{E_{A}}{R T}\right)
$$

Apparent viscosity can also be predicted as a function of temperature, concentration, and a shear rate range by the triparametric mathematical model below (Equation 8) (STEFFE, 1996).

$$
\mu=A_{3} \dot{\gamma}^{n-1} \exp \left(B_{3} C+\frac{E_{A}}{R T}\right)
$$

The model's parameters $\left(A_{3}, n^{-1}, E_{A}\right.$, and $\left.B_{3}\right)$ were obtained by multiple linear regression from the experimental data.

\subsection{Statistical analysis}

The experimental data were fitted according to rheological models using the Origin 8.0 (OriginLab, Middleboro-MA, USA) software to obtain the rheological and statistical parameters $\left(R^{2}\right.$ and $\left.\chi^{2}\right)$. The values of $R^{2}$ and $\chi^{2}$ were obtained to evaluate the goodness of fit to the experimental results of the rheological models.

\section{Results and discussion}

\subsection{Physicochemical properties}

Malay apple has a high moisture content (90.91g/100 g), being considered a juicy fruit. Another relevant characteristic is its low pH level (3.6), which favors its industrialization by avoiding the acidification on jelly and jams processing steps. Other characteristics were: acidity: 0.68 (g/100 g); total solids: 9.08 (g/100 g), and soluble solids: 7.8 ( ${ }^{\circ}$ Brix).

The physicochemical characteristics of malay apple fruit are in accordance with the values observed by Whistler and Elevitch (2006) when studying the physicochemical characteristics of the same fruit. 
Influence of temperature, concentration and shear rate on the rheological behavior of malay apple (Syzygium malaccense) juice Santos, P. H. et al.

The soluble solids concentration of diluted malay apple juice samples were 5.8, 5.1, and $4.4^{\circ}$ Brix for 20, 30 , and $40 \mathrm{~g}$ of water/100 g sample, respectively.

\subsection{Rheological measurements and modeling}

Figure 1 shows the rheograms of experimental shear stress and shear rate of malay apple juice for four concentrations at the temperature range of $10-70{ }^{\circ} \mathrm{C}$. With no shear rates, the fruit juices are stable and only the Brownian motion is responsible for molecular agitation. According to Carreau et al. (1999), the Brownian motion allows the intermolecular attraction forces to promote the formation of flakes, gels, and networks with low molecular resistance. The application of shear rates induces the establishment of hydrodynamic forces, which quickly
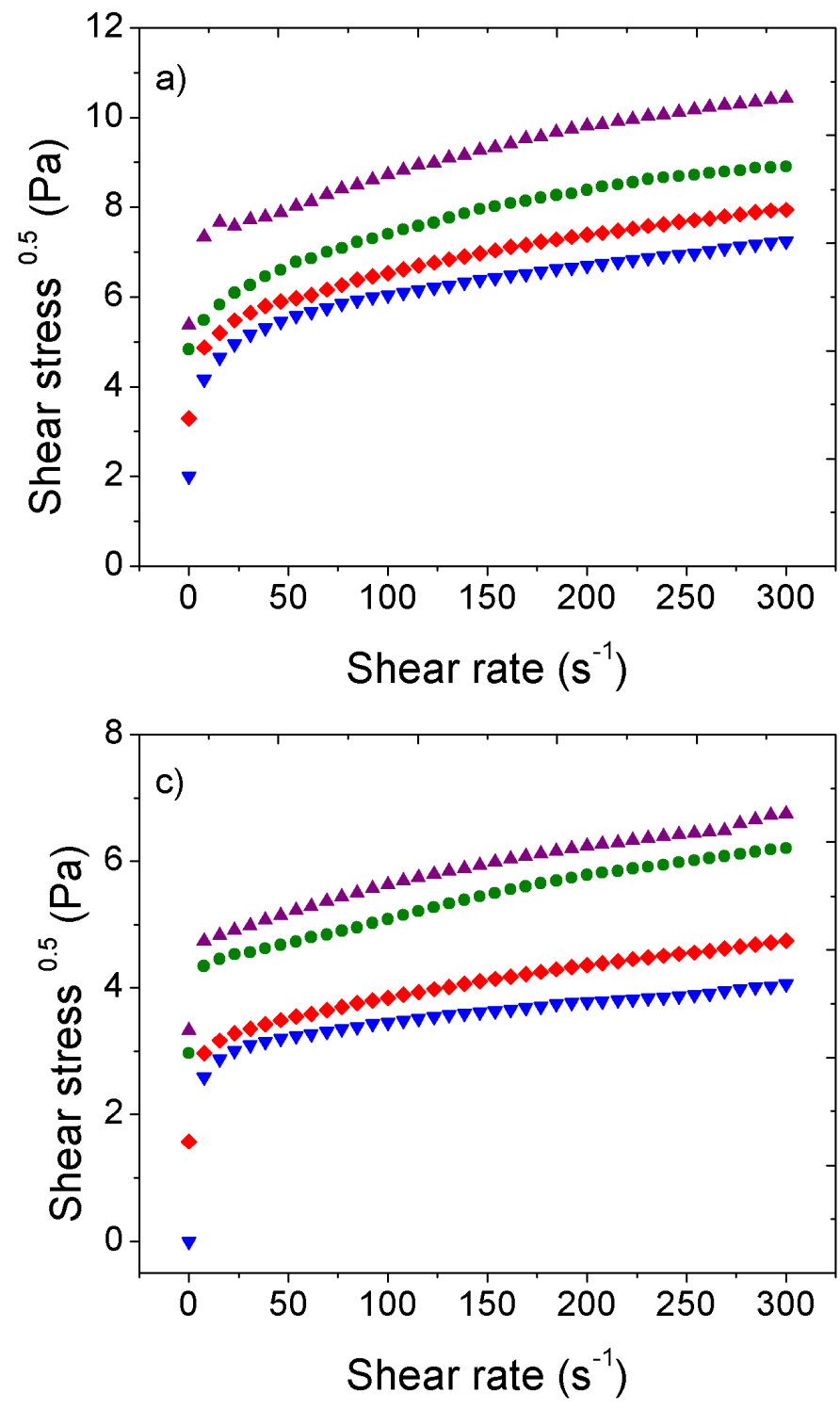

break the weak molecular structure initially formed, thus decreasing the apparent viscosity of the juices. The shear stress values initially grow linearly as a Newtonian fluid and tend to stability at higher shear rates. The shear stress values also showed lower magnitudes at higher temperatures and lower soluble solids concentrations, a typical behavior of pseudoplastic (non-Newtonian) fluids.

All the rheological models were satisfactorily adjusted to the experimental data and presented $R^{2}>0.90$ and $\chi^{2}$ close to zero.

Due to the highest values for $R^{2}$ and the lowest values of $\chi^{2}$ for four concentrations, the Mizrahi-Berk model was used as representative. This model was developed as a modified Casson model to represent the interaction of particles in a concentrated orange juice and
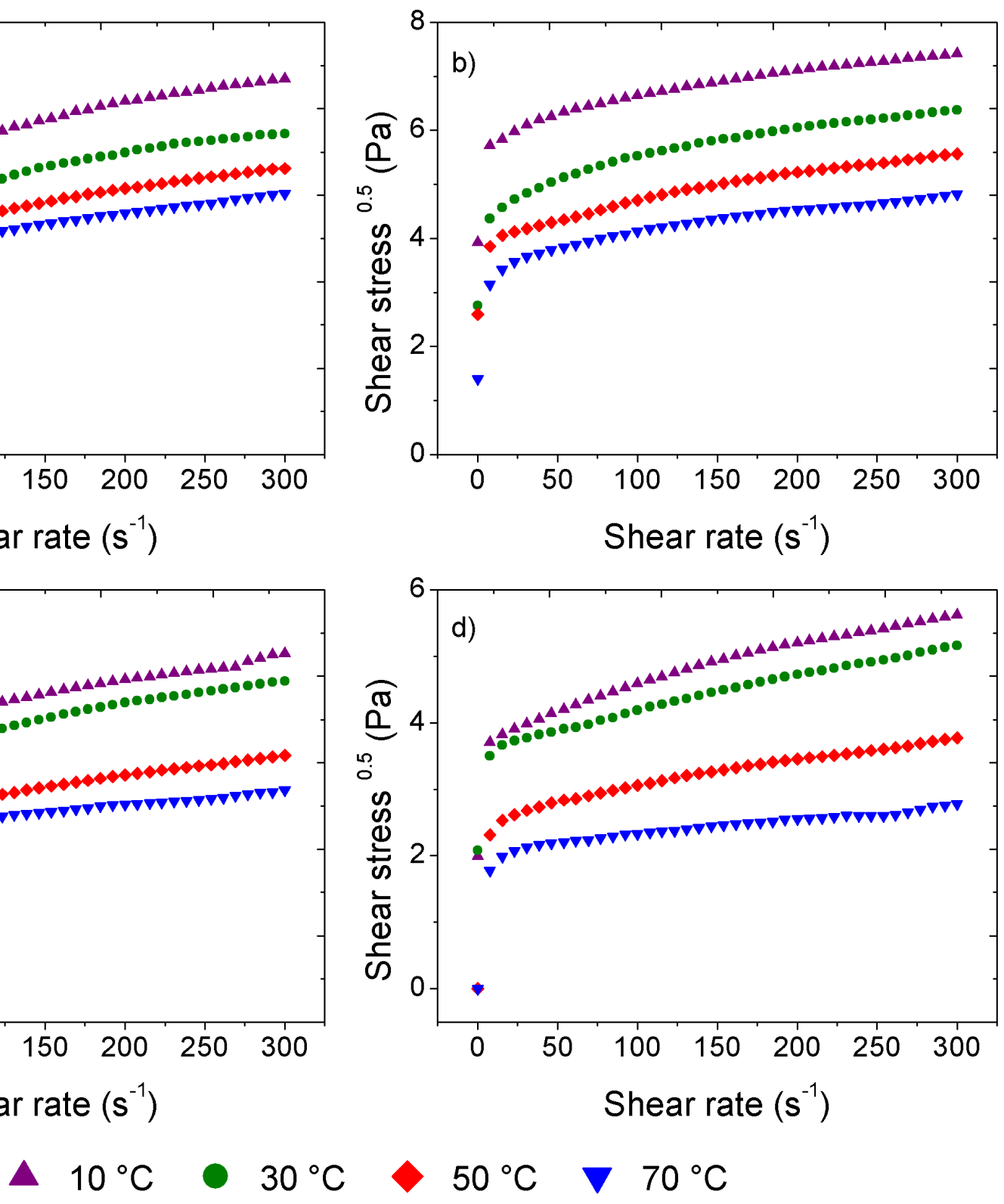

Figure 1. Flow curves of malay apple juice samples at (a) $7.8^{\circ} \mathrm{Brix}$; (b) $5.8^{\circ} \mathrm{Brix}$; (c) $5.1^{\circ} \mathrm{Brix}$ and (d) $4.4^{\circ} \mathrm{Brix}$. 
in other pseudoplastic solvents (MIZRAHI; BERK, 1972). The Mizrahi-Berk model parameters are shown in Table 1. This model has also been used as a representative model for carrot juices (VANDRESEN et al., 2009), pineapple and mango juices (PELEGRINE et al., 2002), and natural guava juice (FERREIRA et al., 2002).

Table 1 shows that the diluted samples presented a pseudoplastic behavior, similar to the natural samples, with flow behavior index lower than 0.5 . This proves that the distilled water added to the natural sample associated to high temperatures was not enough to cause a flow transition from pseudoplastic (a non-Newtonian behavior) to Newtonian.

The consistency index did not show a regular behavior with changes in temperature and concentration. However, the yield stress values decreased as temperature and dilution increased. This suggested that malay apple juice concentrates have a network structure that requires a certain amount of force to be disrupted before flow could occur.

\subsubsection{Effect of temperature and concentration on rheological behavior}

There are currently several factors which may alter rheological behavior of food fluids such as temperature, concentration, and particle size (TONON et al., 2009).
However, the most studied ones are temperature and soluble solids content (GUEDES et al., 2010).

A slight change in temperature may impact rheological behavior. As temperature increases, molecules thermal energy increases and molecular distances develop due to reduction of intermolecular forces hence viscosity of fluid decreases (ARSLAN, 2003). According to Schramm (2006), the temperature variation limit in a rheological test should not exceed the range of $0.1^{\circ} \mathrm{C}$. A rise in temperature increases molecular motion, thus decreasing the juice's viscosity. The constants $A_{0}$ and $E_{A}$ from the Arrhenius equation, $A_{1}$ and $B_{1}$ from the exponential equation, and the relative values of temperature, concentration, and $R^{2}$ are listed in Table 2.

Table 2 shows a satisfactory goodness of fit on the Arrhenius equation for the malay apple samples, with $R^{2}>0.900$. Activation energy increased as concentration decreased. According to Steffe (1996) and Rao (1999), the activation energy indicates the influence of temperature on the apparent viscosity of fluids. According to those authors, the higher the activation energy, the higher the apparent viscosity variation in a temperature range.

Table 1. Rheological parameters of the Mizrahi-Berk model fitted to experimental data of malay apple juice samples.

\begin{tabular}{|c|c|c|c|c|c|c|}
\hline$C\left({ }^{\circ}\right.$ Brix $)$ & $T\left({ }^{\circ} \mathrm{C}\right)$ & $K_{0}$ (Pa.s) & $K_{M B}\left(P a . s^{n}\right)$ & $\begin{array}{c}n_{M B} \\
\text { (adimensional) }\end{array}$ & $R^{2}$ & $\chi^{2}$ \\
\hline \multirow{4}{*}{7.8} & 10 & $5.591 \pm 0.132$ & $0.596 \pm 0.075$ & $0.366 \pm 0.019$ & 0.984 & 0.019 \\
\hline & 30 & $4.727 \pm 0.053$ & $0.357 \pm 0.024$ & $0.437 \pm 0.010$ & 0.997 & 0.003 \\
\hline & 50 & $3.347 \pm 0.041$ & $0.754 \pm 0.027$ & $0.316 \pm 0.005$ & 0.998 & 0.002 \\
\hline & 70 & $2.001 \pm 0.039$ & $1.438 \pm 0.033$ & $0.225 \pm 0.003$ & 0.998 & 0.002 \\
\hline \multirow{4}{*}{5.8} & 10 & $3.952 \pm 0.037$ & $1.050 \pm 0.033$ & $0.207 \pm 0.004$ & 0.997 & 0.001 \\
\hline & 30 & $2.273 \pm 0.022$ & $0.916 \pm 0.018$ & $0.240 \pm 0.003$ & 0.999 & 0.000 \\
\hline & 50 & $2.659 \pm 0.056$ & $0.567 \pm 0.051$ & $0.284 \pm 0.010$ & 0.991 & 0.003 \\
\hline & 70 & $1.408 \pm 0.026$ & $1.189 \pm 0.024$ & $0.182 \pm 0.003$ & 0.998 & 0.001 \\
\hline \multirow{4}{*}{5.1} & 10 & $3.429 \pm 0.075$ & $0.519 \pm 0.050$ & $0.318 \pm 0.014$ & 0.987 & 0.006 \\
\hline & 30 & $3.130 \pm 0.097$ & $0.422 \pm 0.059$ & $0.345 \pm 0.020$ & 0.978 & 0.010 \\
\hline & 50 & $1.633 \pm 0.058$ & $0.686 \pm 0.045$ & $0.260 \pm 0.009$ & 0.991 & 0.003 \\
\hline & 70 & $0.005 \pm 0.038$ & $2.035 \pm 0.041$ & $0.117 \pm 0.003$ & 0.997 & 0.001 \\
\hline \multirow{4}{*}{4.4} & 10 & $2.079 \pm 0.079$ & $0.756 \pm 0.060$ & $0.267 \pm 0.011$ & 0.987 & 0.006 \\
\hline & 30 & $2.191 \pm 0.095$ & $0.580 \pm 0.070$ & $0.279 \pm 0.017$ & 0.973 & 0.009 \\
\hline & 50 & $0.019 \pm 0.061$ & $1.606 \pm 0.063$ & $0.144 \pm 0.005$ & 0.991 & 0.004 \\
\hline & 70 & $0.004 \pm 0.039$ & $1.418 \pm 0.043$ & $0.111 \pm 0.004$ & 0.992 & 0.002 \\
\hline
\end{tabular}

Table 2. Parameters of the Arrhenius and exponential equations for malay apple juice samples at $100 \mathrm{~s}^{-1}$

\begin{tabular}{|c|c|c|c|c|c|c|c|}
\hline \multicolumn{4}{|c|}{ Arrhenius equation } & \multicolumn{4}{|c|}{ Exponential equation } \\
\hline$C\left({ }^{\circ}\right.$ Brix $)$ & $A_{0}$ (Pa.s) & $E_{A}\left(\mathrm{~kJ} \cdot \mathrm{mol}^{-1}\right)$ & $\boldsymbol{R}^{2}$ & $T\left({ }^{\circ} \mathrm{C}\right)$ & $A_{1}$ (mPa.s) & $B_{1}\left({ }^{\circ}\right.$ Brix $\left.^{-1}\right)$ & $R^{2}$ \\
\hline 7.8 & 1.03E-02 & $10.097 \pm 0.707$ & 0.985 & 10 & 4.82E-02 & $0.363 \pm 0.045$ & 0.955 \\
\hline 5.8 & 1.94E-03 & $12.784 \pm 0.184$ & 0.999 & 30 & 5.01E-02 & $0.310 \pm 0.035$ & 0.963 \\
\hline 5.1 & 8.97E-04 & $13.998 \pm 2.274$ & 0.925 & 50 & 1.64E-02 & $0.427 \pm 0.051$ & 0.969 \\
\hline 4.4 & 8.95E-05 & $18.667 \pm 3.522$ & 0.900 & 70 & 7.34E-03 & $0.514 \pm 0.098$ & 0.900 \\
\hline
\end{tabular}


The value of $10.097 \mathrm{~kJ} \mathrm{~mol}^{-1}$ found for the natural malay apple juice $\left(7.8^{\circ}\right.$ Brix) is in accordance with other studies carried out with fruits such as strawberries analyzed by Bezerra et al. (2009), peach purées by Guerrero and Alzamora (1998) and araçá pulp by Haminiuk et al. (2006). Lopes et al. (2013) studied the influence of a wide temperature range (from $20^{\circ} \mathrm{C}$ to $98^{\circ} \mathrm{C}$ ) on the rheological behavior of Brazilian cherry pulp. They found an activation energy of $12.3 \mathrm{~kJ}_{\mathrm{mol}}{ }^{-1}$, at $100 \mathrm{~s}^{-1}$, the same reference shear rate used in the present work. According to the values obtained, temperature has a greater influence on the apparent viscosity of the most diluted sample (4.4 $\left.{ }^{\circ} \mathrm{Brix}\right)$. Among concentrations, apparent viscosity of the natural sample $\left(7.8^{\circ}\right.$ Brix $)$ is the least affected by temperature.

The activation energy from Arrhenius equation is obtained by plotting the logarithm of apparent viscosity versus inverse temperature. The slope multiplied by the universal gas constant gives the value of activation energy. The greater the slope, the higher the activation energy. Figure 2 shows the steeper slope obtained with the lower soluble solids concentration (4.4 ${ }^{\circ} \mathrm{Brix}$ ) which analogously had the highest activation energy.

Similar results have been reported by Sousa et al. (2014), Quek et al. (2013) and Silva et al. (2005), who observed that activation energy increased as soluble solids of pequi pulp, soursop juice and acerola juice, respectively, decreased.

Dak et al. (2007) obtained increasing activation energy values as a consequence of lower solids content of Kesar mango juice.

Activation energy also gradually increased when Totapuri mango solids concentration decreased, as reported by Dak et al. (2006).

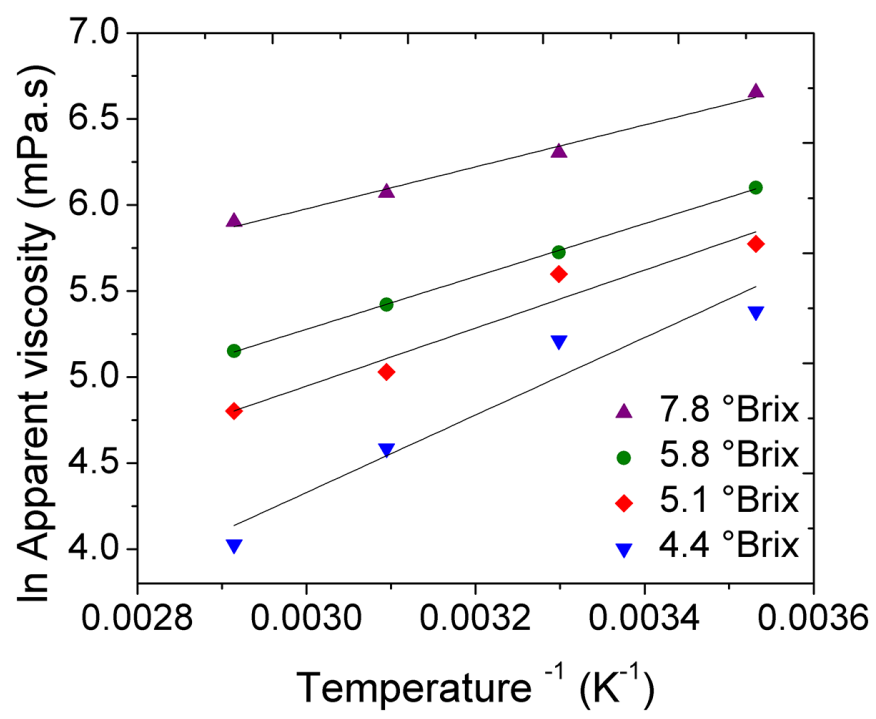

Figure 2. Temperature dependency of apparent viscosity at $100 \mathrm{~s}^{-1}$ obtained from the Mizrahi-Berk model.
Nevertheless, Khalil et al. (1989) examined the influence of temperature on clarified banana juice and realized that activation energy increased with a higher soluble solids concentration. The same behavior was found in studies performed with clarified orange juice (IBARZ et al., 1994) and homogenized peach juice (TORALLES et al., 2006).

In the study developed by Chin et al. (2009), the highest activation energy was obtained at an intermediate concentration. According to the authors, there are inconsistent reports about changes in activation energy with concentration. While some authors observe the highest activation energy in less concentrated products, others report the highest activation energy in line with the maximum soluble solids concentration.

According to Chin et al. (2009), activation energy decreases with the presence of suspended solid particles in fruit juices, which may be the differential matter among the aforementioned studies.

Since no studies have been found related to the rheology of malay apple juice, it was not possible to compare the activation energy values found in the present study with other researches. Nevertheless, the magnitude of the activation energy values for fruit juices, pulps and purées (QUEK et al., 2013; BEZERRA et al., 2009; GUERRERO; ALZAMORA, 1998; LOPES et al., 2013; SILVA et al., 2005; DAK et al., 2006, 2007) are in accordance with the present study.

According to Rao (1999), the soluble and insoluble solids concentrations are seen as one of the key components in identifying a rheological behavior. Soluble solids are mainly composed of carbohydrates (sugars). Carbohydrates have the ability to fix water. Carbohydrate-water interactions produce not only a special arrangement of water molecules around the solute, but also affect solute's conformation. At higher carbohydrates concentrations, the complex carbohydrate-water interaction reduces the system's free energy and, consequently, not all the water is available to hydrate the particles (BENÍTEZ et al., 2009). The effect of soluble solids concentration on apparent viscosity of fluids may be described by two equations - the potential and the exponential equations (STEFFE, 1996; RAO, 1999). In this study, an exponential equation was applied to evaluate the effect of soluble solids concentration of malay apple samples.

The exponential equation has also been used with great accuracy to assess the soluble solids concentration in pomelo juice (KESHANI et al., 2012), watermelon pulp (GUEDES et al., 2010), acerola juice (SILVA et al., 2005), and peach purée (GUERRERO; ALZAMORA, 1998).

Table 2 shows an abrupt decrease in the pre-exponential factor $\left(A_{0}\right)$. On the other hand, the exponential factor $\left(A_{1}\right)$ related to soluble solids concentration increases with temperature, showing that changes in soluble solids 
concentration, for the same pattern, affect more viscosity at high temperatures.

Figure 3 shows a steeper line at $70^{\circ} \mathrm{C}$ in comparison with the other ones, showing a large disparity between the points referring to the apparent viscosity. Thus, the value of parameter $A_{1}$ is higher.

These results are in accordance with Silva et al. (2005), who have also observed a decrease in parameter $A_{0}$ and an increase in parameter $A_{1}$ as temperature increases. Guerrero and Alzamora (1997) obtained a decrease in the values of parameter $A_{0}$ with higher temperatures for banana purée, a similar effect to the one found in the present study. A similar effect was reported by Chin et al. (2009) with grapefruit juice by applying the potential equation.

However, some authors noticed a distinct behavior on the exponential equation parameters with an increase in temperature, showing a greater influence on the soluble solids concentration in low temperatures.

An increase and a decrease on parameters $A_{0}$ and $A_{1}$, respectively, were obtained with the study of the rheology of clarified orange juice by Ibarz et al. (1994), who noticed a Newtonian behavior. The authors used exponential and potential models to evaluate the influence of soluble solids on viscosity.

The behavior of exponential equation parameters with temperature increase may be due to the rheological behavior observed. Pseudoplastic fluids show an increase in the values of parameter $A_{1}$ with higher temperatures, whereas the opposite behavior was observed in parameter $A_{1}$ for Newtonian fluids. Therefore, it can be seen that there is no general behavior for $A_{0}$ and $A_{1}$ in the exponential equation as temperature increases.

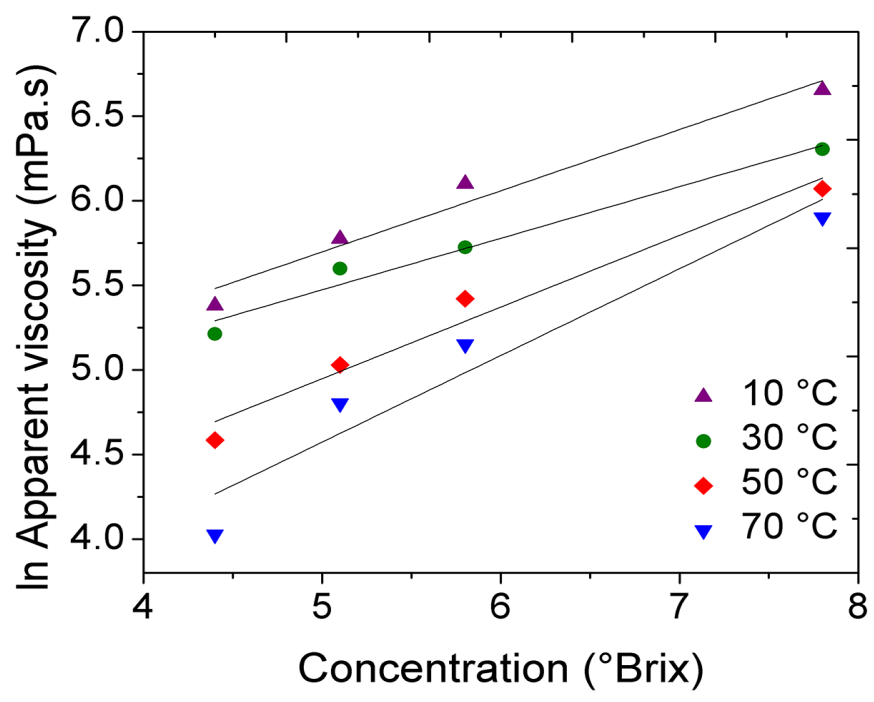

Figure 3. Concentration dependency of apparent viscosity at $100 \mathrm{~s}^{-1}$ obtained from the Mizrahi-Berk model.
An equation combining temperature and concentration (Equation 9) was derived from the linearized Equation 7. A multiple linear regression was accomplished to estimate the three equation parameters $A_{2}, B_{2}$, and $E_{A}$.

$$
\begin{gathered}
\mu=0.104 \exp \left(0.408 C+\frac{13.869}{\mathrm{R} T}\right) \\
R^{2}=0.943
\end{gathered}
$$

It should be emphasized that this equation is applicable only for concentrations within the range of 4.4 to $7.8^{\circ} \mathrm{Brix}$ and temperatures between $10^{\circ} \mathrm{C}$ and $70^{\circ} \mathrm{C}$.

These results show that apparent viscosity increases with higher soluble solids concentration and lower temperature. Similar results were reported by Gabsi et al. (2013) on date syrup concentrates and by Quek et al. (2013) on soursop juice concentrates.

\subsubsection{Combined effect of temperature, concentration, and shear rate on rheological behavior}

For a shear rate ranging from 100 to $300 \mathrm{~s}^{-1}$, usually applied in industrial juice processing, an equation combining temperature, concentration, and shear rate (Equation 10) was developed by multiple linear regression.

$$
\mu=2.311 \dot{\gamma}^{-0.678} \exp \left(0.409 C+\frac{13.938}{R T}\right)
$$

$$
R^{2}=0.878
$$

Due to the highly satisfactory goodness of fit, $R^{2}>0.870$, Equation 9 and Equation 10 could be appropriately applied to industrial processes involving malay apple juice.

\section{Conclusion}

Malay apple juice, obtained from fruits with skin, showed a pseudoplastic behavior. The Power Law, Herschel-Bulkley, and Sisko models showed a good fit to the experimental data. However, the Mizrahi-Berk model was chosen due to its higher goodness of fit. The Arrhenius and exponential equations satisfactorily represented the influence of temperature and concentration on samples' apparent viscosity, respectively. It was observed that apparent viscosity was more sensitive to changes such as increased temperature and dilution.

A triparametric mathematical model combining temperature, concentration, and shear rate was proposed in the research and satisfactorily represented the effect of the three variables on the apparent viscosity of natural and diluted malay apple juice with high $\mathrm{R}^{2}$ coefficient, allowing its application in industrial juice processes involving malay apple fruit.

\section{References}

ARSLAN, E. Rheological characterization of tahin/pekmez (sesame paste/concentrated grape juice) blends. 2003. 59 p. 
Influence of temperature, concentration and shear rate on the rheological behavior of malay apple (Syzygium malaccense) juice Santos, P. H. et al.

Dissertation (Masters in Science)-Middle East Technical University, Department of Food Engineering, Ancara, 2003

AUGUSTA, I. M.; RESENDE, J. M.; BORGES, S. V.; MAIA, M. C. A.; COUTO, M. A. P. G. Caracterização física e química da casca e polpa de jambo vermelho (Syzygiummalaccensis, (L.) Merryl\& Perry). Ciência e Tecnologia de Alimentos, Campinas, v. 30, n. 4, p. 928-932, 2010. http://dx.doi.org/10.1590/S010120612010000400014

BENÍTEZ, E. I.; GENOVESE, D. B.; LOZANO, J. E. Effect of typical sugars on the viscosity and colloidal stability of apple juice. Food Hydrocolloids, Oxford, v. 23, n. 2, p. 519-525, 2009. http://dx.doi.org/10.1016/j.foodhyd.2008.03.005.

BEZERRA, J. R. M. V.; RIGO, M.; DEMCZUK JUNIOR, B.; CÓRDOVA, K. R. V. Estudo do efeito da temperatura nas propriedades reológicas da polpa de morango (Fragaria ananassa). Ambiência, Guarapuava, v. 5, n. 1, p. 37-47, 2009.

CARREAU, P. J.; LAVOIE, P. A.; YZIQUEL, F. Rheological properties of concentrated suspensions. In: SIGINER, D. A., KEE, D., CHHABRA, R. P. Advances in the flow and rheology of non-Newtonian fluids: part A. New York: Elsevier, 1999. chap. 8, p. 1299-1345. (Rheology Series).

CHIN, N. L.; CHAN, S. M.; YUSOF, Y. A.; CHUAH, T. G.; TALIB, R. A. Modelling of rheological behaviour of pummelo juice concentrates using master-curve. Journal of Food Engineering, Essex, v. 93, n. 2, p. 134-140, 2009. http://dx.doi.org/10.1016/j. jfoodeng.2009.01.005.

DAK, M.; VERMA, R. C.; JAAFFREY, S. N. A. Effect of temperature and concentration on rheological properties of "Kesar" mango juice. Journal of Food Engineering, Essex, v. 80, n. 4, p. 10111015, 2007. http://dx.doi.org/10.1016/j.jfoodeng.2006.08.011.

DAK, M.; VERMA, R. C.; SHARMA, G. P. Flow characteristics of juice of "Totapuri" mangoes. Journal of Food Engineering, Essex, v. 76, n. 4, p. 557-561, 2006. http://dx.doi.org/10.1016/j. jfoodeng.2005.06.002.

FERREIRA, G. M.; QUEIROZ, A. J. M.; CONCEIÇÃO, R. S.; GASPARETTO, C. Efeito da temperatura no comportamento reológico das polpas de caju e goiaba. Revista Ciências Exatas e Naturais, Guarapuava, v. 4, n. 2, p. 175-184, 2002.

GABSI, K.; TRIGUI, M.; BARRINGTON, S.; HELAL, A. N.; TAHERIAN, A. R. Evaluation of rheological properties of date syrup. Journal of Food Engineering, Essex, v. 117, n. 1, p. 165-172, 2013. http://dx.doi.org/10.1016/j.jfoodeng.2013.02.017.

GUEDES, D. B.; RAMOS, A. M.; DINIZ, M. D. M. S. Efeito da temperatura e da concentração nas propriedades físicas da polpa de melancia. Brazilian Journal of Food Technology, Campinas, v. 13, n. 4, p. 279-285, 2010. http://dx.doi.org/10.4260/ BJFT2010130400037.

GUERRERO, S. N.; ALZAMORA, S. M. Effect of pH, temperature and glucose addition on flow behaviour of fruit purées I. Banana purée. Journal of Food Engineering, Essex, v. 33, n. 3-4, p. 239-256, 1997

GUERRERO, S. N.; ALZAMORA, S. M. Effects of $\mathrm{pH}$, temperature and glucose addition on flow behaviour of fruit purées: II. Peach, papaya and mango purées. Journal of Food Engineering, Essex, v. 37, n. 1, p. 77-101, 1998. http://dx.doi.org/10.1016/ S0260-8774(98)00065-X.

HAMINIUK, C. W. I.; SIERAKOWSKI, M. R.; VIDAL, J. R. M. B.; MASSON, M. L. Influence of temperature on the rheological behavior of whole araçá pulp (Psidium cattleianum sabine). Lebensmittel-Wissenschaft und-Technologie, Switzerland, v. 39, n. 4, p. 426-430, 2006.

IBARZ, A.; GARVIN, A.; COSTA, J. Rheological behaviour of sloe (Prunus spinosa) fruit juices. Journal of Food Engineering, Essex, v. 27, n. 4, p. 423-430, 1996. http://dx.doi.org/10.1016/02608774(95)00024-0.

IBARZ, A.; GONZALEZ, C.; ESPLUGAS, S. Rheology of clarified fruit juices III: orange juices. Journal of Food Engineering, Essex, v. 21 , n. 4 , p. 485-494, 1994. http://dx.doi.org/10.1016/02608774(94)90068-X

IBARZ, A.; PAGÁN, J.; MIGUELSANZ, R. Rheology of clarified fruit juices II: blackcurrant juices. Journal of Food Engineering, Essex, v. 15, n. 1, p. 63-73, 1992. http://dx.doi.org/10.1016/02608774(92)90040-D.

INSTITUTO ADOLFO LUTZ - IAL. Métodos físico-químicos para análise de alimentos. 4th. ed. São Paulo: Instituto Adolfo Lutz, 2008. 1020 p.

KAYA, A.; BELIBAGLI, K. B. Rheology of solid Gaziantep pekmez. Journal of Food Engineering, Essex, v. 54, n. 3, p. 221-226, 2002. http://dx.doi.org/10.1016/S0260-8774(01)00205-9.

KESHANI, S.; CHUAH, A. L.; RUSSLY, A. R. Effect of temperature and concentration on rheological properties pomelo juice concentrates. International Food Research Journal, Malaysia, v. 19, n. 2, p. 553-562, 2012.

KHALIL, K. E.; RAMAKRISHNA, P.; NANJUNDASWAMY, A. M.; PATWARDHAN, M. V. Rheological behaviour of clarified banana juice: effect of temperature and concentration. Journal of Food Engineering, Essex, v. 10, n. 3, p. 231-240, 1989. http://dx.doi. org/10.1016/0260-8774(89)90028-9.

LOPES, A. S.; MATTIETTO, R. A.; MENEZES, H. C.; SILVA, L. H. M.; PENA, R. S. Rheological behavior of brazilian cherry (Eugenia uniflora L.) pulp at pasteurization temperatures. Food Science and Technology, Campinas, v. 33, n. 1, p. 26-31, 2013. http:// dx.doi.org/10.1590/S0101-20612013005000001.

MIZRAHI, S.; BERK, Z. Flow behavior of concentrated orange juice: mathematical treatment. Journal of Texture Studies, Dordrecht, v. 3, n. 1, p. 69-79, 1972. http://dx.doi.org/10.1111/j.1745-4603.1972. tb00610.x. 
Influence of temperature, concentration and shear rate on the rheological behavior of malay apple (Syzygium malaccense) juice Santos, P. H. et al.

NINDO, C. I.; TANG, J.; POWERS, J. R.; TAKHAR, P. S. Rheological properties of blueberry purée for processing applications. Journal of Food Engineering, Essex, v. 40, n. 1, p. 292-299, 2007.

PELEGRINE, D. H.; SILVA, F. C.; GASPARETTO, C. A. Rheological behavior of pineapple and mango pulps. Lebensmittel-Wissenschaft und-Technologie, Switzerland, v. 35, n. 8, p. 645-648, 2002.

QUEK, M. C.; CHIN, L. N.; YUSOF, Y. A. Modelling of rheological behavior of soursop juices concentrates using shear ratetemperature-concentration superposition. Journal of Food Engineering, Essex, v. 118, n. 4, p. 380-386, 2013. http://dx. doi. org/10.1016/j.jfoodeng.2013.04.025.

RAO, A. M. Rheology of fluid and semisolid fluids: principles and applications. Maryland: Aspen Publication, 1999. 433 p.

SCHRAMM, G. Reologia e reometria: fundamentos teóricos e práticos. 2nd. ed. Karlsruhe: Artliber, 2006. 232 p.

SILVA, F. C.; GUIMARÃES, D. H. P.; GASPARETTO, C. A. Reologia do suco de acerola: efeitos da concentração e temperatura. Ciência e Tecnologia de Alimentos, Campinas, v. 25, n. 1, p. 121-126, 2005. http://dx.doi.org/10.1590/S0101-20612005000100020.

SOUSA, E. P.; QUEIROZ, A. J. M.; FIGUEIRÊDO, R. M. F.; LEMOS, D. M. Comportamento reológico e efeito da temperatura da polpa de pequi em diferentes concentrações. Brazilian Journal of Food Technology, Campinas, v. 17, n. 3, p. 226-235, 2014. http://dx.doi.org/10.1590/1981-6723.1214.
STEFFE, J. F. Rheological methods in food process engineering. 2nd. ed. Michigan: Freeman Press, 1996. 418 p.

TELIS-ROMERO, J.; TELIS, V. R. N.; YAMASHITA, V. R. N. Friction factors and rheological properties of orange juice. Journal of Food Engineering, Essex, v. 40, n. 1-2, p. 101-106, 1999.

TONON, R. V.; ALEXANDRE, D.; HUBINGER, M. D.; CUNHA, R. L. Steady and dynamic shear rheological properties of acai pulp (Euterpe oleracea Mart.). Journal of Food Engineering, Essex, v. 92, n. 4, p. 425-431, 2009. http://dx.doi.org/10.1016/j. jfoodeng.2008.12.014.

TORALLES, R. P.; VENDRUSCOLO, J. L.; VENDRUSCOLO, C. T. Reologia de purê homogeneizado de pêssego: efeito da temperatura e concentração. Brazilian Journal of Food Technology, Campinas, v. 9, n. 1, p. 1-8, 2006.

VANDRESEN, S.; QUADRI, M. G. N.; SOUZA, J. A. R.; HOTZA, D. Temperature effect on the rheological behavior of carrot juices. Journal of Food Engineering, Essex, v. 92, n. 3, p. 269-274, 2009. http://dx.doi.org/10.1016/j.jfoodeng.2008.11.010.

WHISTLER, W. A.; ELEVITCH, C. R. Syzygium malaccense (Malay apple). In: ELEVITCH, C. R. Species profiles for Pacific Island agroforestry. Holualoa: Permanent Agriculture Resources, 2006. p. 1-13. Available from: <http://www.traditionaltree.org>. Access in: 17 mar. 2015. 